\title{
Retraction Note to: Groundwater level change based on edge computing and translation accuracy of urban English
}

\author{
Yan $\mathrm{Li}^{1}$
}

Published online: 3 November 2021

C) Saudi Society for Geosciences 2021

Retraction Note to: Arabian Journal of Geosciences (2021) 14: 1682 https://doi.org/10.1007/s12517-021-08068-1

The Editor-in-Chief and the Publisher have retracted this article because the content of this article is nonsensical. The peer review process was not carried out in accordance with the Publisher's peer review policy. The author has not responded to correspondence regarding this retraction.

The original article can be found online at https://doi.org/10.1007/ s12517-021-08068-1.

Yan Li

yan_8706091ele@126.com

1 Department of Foreign Language, Shaanxi University of Chinese Medicine, Xi' an-Xianyang New Economic Zone, Xianyang, Shaanxi, China 